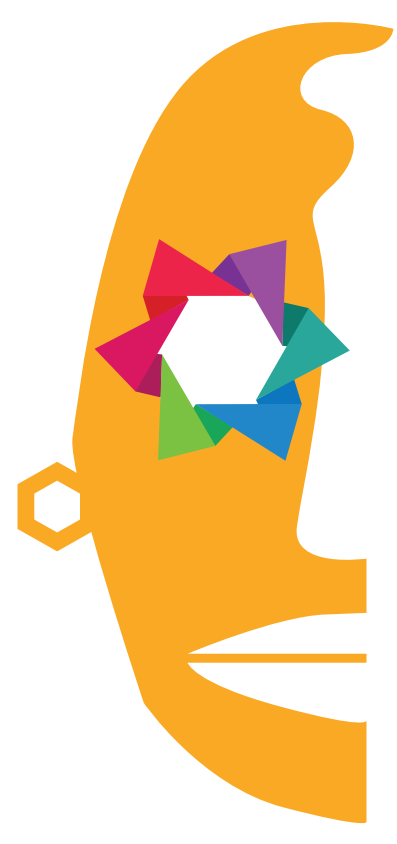

Laura Fuentes

Belgrave

Directora Revista Ístmica

\title{
Antigua luna (2017) de Magda Zavala
}

\section{Ancient Moon (2017) by Magda Zavala}

La ciudad de Antigua, en Guatemala, ha sido y continúa siendo evocada a través de la palabra diluida en la historia y la memoria. Prueba de ello es el libro Poesía-documento, titulado Antigua Luna (2017), de la escritora costarricense Magda Zavala, publicado en 2017 por la editorial Letra Maya, dentro de la Colección Kayab, en Costa Rica. Este poemario, dividido en tres secciones; $I$. Capital de los Confines, II. Espacios y voces y III. La visitante, recoge entre sus versos los resabios coloniales de un pasado épico, que convive con un presente transnacional y postmoderno. Ahí es donde los cimientos indígenas sostienen identidades en permanente reconstrucción, aprendida a través de cinco siglos de sobrevivencia en la desigualdad.

De Antigua Luna (2017), en esta edición N. 26 de Ístmica, reproducimos tres poemas pertenecientes a la segunda sección del libro, donde el despojo histórico y el avance mercantil, la guerra interna y la paz firmada, se abrazan en la realidad vivida. 
La poeta y narradora Magda Zavala, es también investigadora especialista en literatura centroamericana, así como filóloga y educadora graduada de la Universidad de Costa Rica. Obtuvo una Maestría en la Universidad de Lyon II, en Francia, y un Doctorado en Letras de la Universidad de Lovaina la Nueva, en Bélgica. Sus publicaciones literarias son: Desconciertos en un jardin tropical (novela, 1999), Tríptico de las mareas (poesía, 2010) y Antigua Luna (poesía, 2017). En el campo académico ha publicado: Con mano de mujer. Antología de poetas centroamericanas contemporáneas [1970-2008] (2011); y en coautoría: Mujeres en las literaturas indigenas y afrodescendientes en América Central (con Consuelo Meza Márquez, 2015), Literaturas indigenas de América Central (2002), e Historiografía literaria de América Central (1995), ambos en coautoría con Seidy Araya.

Fue fundadora de la Revista Ístmica y su primera directora en 1994, así como también fue promotora, fundadora y primera directora de otras instituciones académicas y literarias, como la Maestría en Cultura Centroamericana de la Universidad Nacional (UNA, Costa Rica), el Doctorado en letras y Artes en América Central (DILAAC, UNA, Costa Rica), la Fundación INTERARTES (2011-2017) y la Asociación Costarricense de Escritoras (2014-2016), de la que fue promotora y parte del equipo fundador. Fue académica de la Universidad Nacional de Costa Rica y profesora invitada en Noruega, Canadá, Guatemala y Nicaragua.

\section{Huipiles}

Apilados en desorden, con sus constelaciones geométricas

del jaguar y la serpiente, del infinito y sus entresijos, los huipiles usados, refugio del frío, marcadores de las eras (como en la cuenta larga, en la cuenta corta, el tiempo), se venden.

Se ofrecen estas sombras, de colores ya apagados, antes abrigos en cuerpos cakchiqueles y quichés, torsos tzutujiles, 
espaldas pokonchís o pokomames, pechos ixiles, chortís y kekchíes.

Los viejos testigos del frío y del hambre, de tanta pena, en el mercado de Antigua se venden.

(Tomado del poemario: Antigua Luna 2017, 42).

\section{Silencio y desmemoria}

Que el tiempo no olvide los rostros masacrados, lo digo yo que viví la guerra.

Que el silencio no extienda un perdón impúdico sobre los culpables, que la vista gorda pierda pronto sus cómplices, que los gritos de dolor lleguen a los oídos de los sin escucha, que la Comisión de la Verdad no se extinga, que la Memoria del silencio siga hablando, que nazcan niñas con banderas blancas en los ojos y nunca desistan, que se acabe el yo soy grande $\mathrm{y}$ vos pequeño, el soy blanco y vos morena, el tengo poder y vos lo sufrís, el soy fuerte y vos tan disminuido, el soy águila y vos cachorro sin nido.

(Tomado del poemario: Antigua Luna 2017, 51). 


\section{Kaibil}

Balam, Balam

Kaibil mam

con la fuerza y la astucia de dos tigres.

El diente del miedo sin retenes

horadó los muros del templo mayor, las aceras ya rotas, el corazón del parque central y los hoteles;

llegó, sin más, a restaurantes bares y comercios y otras tiendas para residentes; también deambuló por las escuelas y los campos, por las casas aisladas del despoblado, atravesando riachuelos, sin respeto a la propiedad privada. Sacó su aliento por las alcantarillas y anidó en las sacristías.

El miedo tiene una lengua suprema en Guatemala.

El miedo, a veces, avisa.

Un kaibil entrenado por inteligencias múltiples testimonia sus hazañas.

El ojo de felino se enciende en la oscuridad, permanece, adecua su oficio.

(Tomado del poemario: Antigua Luna 2017, 52). 